\title{
Photodynamic action of chlorin e6 against methicillin resistant staphylococcus aureus with the aid of ethanol
}

\author{
Klorin e6'nın etanol yardımıyla metisiline dirençli stafilokok aureus üzerindeki \\ fotodinamik etkisi
}

\author{
Nermin Topaloğlu ${ }^{1}$, Emel Bakay ${ }^{1}$, Aziz Kolkıran ${ }^{2}$
}

\section{Abstract}

Aim: The random use of antimicrobials for years has led to bacterial DNA mutation and a result of that, bacteria have become resistant to antibiotics. Methicillin-resistant Staphylococcus aureus (MRSA) is among these types of resistant bacteria that can easily infect when the immune system of the host is suppressed, and it significantly delays the wound healing. Different treatment methods are being investigated to overcome this problem. Antimicrobial photodynamic therapy is a candidate to become an alternative treatment for the destruction of MRSA. The aim of this study was to investigate the effect of chlorin e6 for the photoinactivation of MRSA and the synergetic role of ethanol in this mechanism.

Methods: $655 \mathrm{~nm}$ laser light and Chlorin e6 as photosensitizer were examined for the photoinactivation of MRSA. Besides, $20 \%$ ethanol was used to increase the total antimicrobial efficacy with lower light energy densities and photosensitizer concentrations. The colony counting method was used to determine viable bacteria cells after each application.

Results: $25 \mathrm{~J} / \mathrm{cm} 2$ energy density with $20 \mu \mathrm{M}$ Chlorin e6 and $50 \mathrm{~J} / \mathrm{cm} 2$ energy density with $10 \mu \mathrm{M}$ Chlorin e6 showed the highest bactericidal activity. When $20 \%$ ethanol was used as an adjuvant, $25 \mathrm{~J} / \mathrm{cm} 2$ energy dose with $2 \mu \mathrm{M}$ Chlorin e6 resulted in a better killing effect.

Conclusion: Chlorin e6-mediated photodynamic therapy was successful to destroy MRSA and the addition of ethanol provided the opportunity to obtain higher antibacterial activity with lower light intensities and photosensitizer concentrations.

Keywords: Antibacterial photodynamic therapy, chlorin e6, ethanol, staphylococcus aureus

Öz

Amaç: Antibiyotiklerin uzun yıllar boyunca kontrolsüz bir şekilde kullanılması bakteriyel DNA mutasyonuna yol açmıştır ve bunun sonucunda bakteriler antibiyotiklere dirençli hale gelmiştir. Metisiline dirençli Stafilokok aureus (MRSA) bakterileri, bu tür dirençli bakteriler arasında olup vücudun bağışıklık sisteminin düşmes sonucu kolayca enfeksiyona sebep olabilmekte ve yara iyileşmesini önemli ölçüde geciktirmektedirler. Bu sorunun üstesinden gelmek için farklı tedavi yöntemleri araştırılmaktadır. Antimikrobiyal fotodinamik tedavi enfeksiyonların yok edilmesine yönelik alternatif bir tedavi olmaya adaydır. Bu çalışmanın amacı ise klorin e6'nın MRSA'nın fotoinaktivasyonu üzerindeki etkisini ve bu mekanizmada etanolün sinerjik rolünü araştırmaktır.

Yöntemler: Bu çalışmada MRSA'nın fotoinaktivasyonu için $655 \mathrm{~nm}$ lazer ışığı ve fotosensitizan olarak Klorin e6 incelenmiştir. Ayrıca, \% 20 etanol kullanımıyla mekanizmanın antimikrobiyal etkinliği düşük ışık enerjisi yoğunlukları ve fotosensitizan konsantrasyonları ile arttırılmaya çalışılmıştır. Her uygulamadan sonra canlı bakteri hücre sayısını belirlemek için koloni sayma yöntemi kullanılmıştır.

Bulgular: Uygulamalar arasında $20 \mu \mathrm{M}$ Klorin e6 ile $25 \mathrm{~J} / \mathrm{cm} 2$ enerji yoğunluğu ve $10 \mu \mathrm{M}$ Klorin e6 ile 50 $\mathrm{J} / \mathrm{cm} 2$ enerji yoğunluğu en yüksek bakterisidal aktiviteyi sağlamıştır. \%20 etanolün mekanizmaya eklenmesiyle en etkili fotosensitizan konsantrasyonu $2 \mu$ M'a düşürülerek $25 \mathrm{~J} / \mathrm{cm} 2$ enerji yoğunluğu ile birlikte daha etkili bir sonuç elde edilebilmiştir.

Sonuç: Klorin e6 aracılı fotodinamik tedavi, MRSA'yı yok etmekte başarılı olmuştur ve etanol ilavesi, daha düşük 1 şı yoğunluğu ve fotosensitizan konsantrasyonu ile fotodinamik tedavide daha yüksek antibakteriyel aktivite elde etme fırsatı sağlamıştır.

Anahtar Kelimeler: Antibakteriyel Fotodinamik Terapi, Klorin e6, Etanol, Stafilokok aureus
1 Izmir Katip Celebi University, Faculty of Engineering and Architecture, Department of Biomedical Engineering, Izmir, Turkey.

2 Izmir Katip Celebi University, Faculty of Engineering and Architecture, Department of Engineering Sciences, Izmir, Turkey.

ID

NT: 0000-0001-7001-8327

EB: 0000-0002-3042-810X

AK: 0000-0002-7440-5428

Ethics Committee Approval: Ethics committee approval was not received due to non-human and non-animal participating design of the study.

Etik Kurul Onayı: Çalışma tasarımının insan ve hayvan katılımlı olmaması nedeniyle etik kurul onayı alınmadı.

Conflict of Interest: No conflict of interest was declared by the authors.

Çıkar Çatışması: Yazar çıkar çatışması bildirmemiștir.

Financial Disclosure: This study was supported by the İzmir Katip Çelebi University Scientific Research Projects (2015-ÖNP-MÜMF-0017 to N.T.)

Finansal Destek: Bu çalışma İzmir Katip Çelebi Üniversitesi Bilimsel Araştırma Projeleri Koordinatörlüğü (2015-ÖNP-MÜMF-0017) tarafından desteklenmiştir.

Some of the data in this manuscript has been presented in Medical Technologies National Congress (TIPTEKNO'17), 12-14 October 2017,

Trabzon, Turkey and Medical Technologies National Congress (TIPTEKNO'18), 8-10 November 2018, Magosa, KKTC.

$\mathrm{Bu}$ yazıda yer alan verilerin bir kısmı Tıbbi Teknolojiler Ulusal Kongresi (TIPTEKNO'17), 1214 Ekim 2017, Trabzon, Türkiye ve Tibbi Teknolojiler Ulusal Kongresi (TIPTEKNO'18), 810 Kasım 2018, Magosa, KKTC'de sunulmuştur.

Gelis Tarihi / Received: 20.05.2020

Kabul Tarihi / Accepted: 29.10.2020 Yayın Tarihi / Published: 15.12.2020

Sorumlu yazar / Corresponding author: Nermin Topaloglu

Adres/Address: Izmir Katip Celebi University Faculty of Engineering and Architecture

Department of Biomedical Engineering İzmir, 35620 Turkey

e-posta: nermin.topaloglu@ikcu.edu.tr

Tel/Phone: +90 232329 3535/3769

Copyright $\odot$ ACEM 


\section{Introduction}

Bacterial infections can cause serious problems in different types of wounds, prolong the wound healing process, and may spread. Thus, infections must be eliminated for complete wound healing. Wound infections are common and may result in morbidity and mortality. Methicillin-resistant Staphylococcus aureus (MRSA) infections, which are common among these types of infections in the hospital and the environment, are increasing day by day [1].

MRSA is a gram-positive bacterial species, found in skin and mucosa by infecting the human body. MRSA, which is usually found in the hospital environment, has been easily transferred between patient-doctor and patient-patient, thus it has become a common pathogen in the hospital and community [2, 3]. Staphylococci are common bacteria of the skin and mucous membranes. They are usually present in high numbers in these parts of the body compared to other microorganisms [4]. Therefore, it can cause a rapid pathogenic effect in areas where the immune system is weakened such as after surgical operations. More than $90 \%$ of the chronic wounds are bacteriaborne diseases that occur in the oral mucosa, the enteric tract, and the superficial areas that damage the healing mechanism [5]. MRSA and similar bacteria can appear and infect in any situation where immune system elements such as B cell, $\mathrm{T}$ cell, antibodies, and neutrophils are repressed $[6,7]$.

MRSA also has a fast DNA repair mechanism against applied antiseptic or antibacterial applications. Therefore, they can easily resist the treatment mechanisms applied. Because of these reasons, researchers have gone on to explore and develop various applications to eliminate the toxic effects created by MRSA. They have carried out various studies on wound infections. Among these studies, the most common and traditional method has been antibiotic treatment [8]. From the past to today, different bacterial agents have been used in the treatment of bacteria. The result of the production of various bacterial toxins has had different effects on the host immune response. In general, agents have been developed to disrupt the synthesis of bacterial cell walls and other important cell organelles such as genetic material [9]. In the medical world, the discovery of antibiotics has made possible the treatment of many microorganism-borne diseases since the 20th century and antibiotics play important role in many fields [10]. Over time, extensive use of antibiotics and rapid mutations of microorganisms against antibiotics has resulted in antibioticresistant microorganisms and these rapid mutations have increased the resistance of these microorganisms [11]. Bacterial resistance is a very important issue as antibiotics become ineffective as bacteria develop ways to counter antibiotics. In this way, the lethal pathogenic bacteria develop and regenerate in poor conditions [12]. As a result of the different and widespread use of antibiotics by humans, many bacteria have become resistant to antibiotics used and have had fatal consequences [13, 14]. MRSA is anxiously resistant bacteria nowadays because of its unique virulence, its ability to cause various infections, and its ability to adapt easily to different environmental conditions and have become resistant to many antibiotics with different mechanisms $[15,16]$. When the resistance mechanisms that occur in MRSA are examined in general; it may limit the drug intake, modify the drug target, perform horizontal gene transfer, provide enzymatic inactivation of the drug, or provide the active efflux of the drug to render the administered antibiotic ineffective [17]. Despite the recent development of new antibiotics, MRSA will continue to develop rapid resistance to existing antibiotics. Therefore, antibiotic therapy does not seem to be a definite recovery [18]. For this reason, researchers have begun to develop alternative and effective solutions instead of traditional antibiotic treatment. The destruction of microorganisms by antimicrobial photodynamic therapy (aPDT) is an effective and widely prescribed alternative technique today.

aPDT, one of the most innovative and promising approaches used in this study, is a valuable therapeutic approach for the elimination of MRSA infections. It is a specific method involving the interaction of non-toxic drug or dye, which is known as photosensitizer (PS), with light at the appropriate wavelength [10]. After light irradiation, the PS jumps from low energy levels to high energy levels and becomes excited. The PS transmits the energy to the bio-macromolecules around it through molecular interaction. High energy transferred from PS to available oxygen molecules forms various free radicals or reactive oxygen species (ROS). These products cause irreversible damage to the bacterial cell [19]. This lethal effect may be in the form of lipid membrane degradation or deterioration of single or double-stranded DNA [11]. The rate of formation of ROS and mechanism of action of aPDT is thought to depend on the duration of application of the PS, its localization on/in the cell, and the biological environment applied [19]. aPDT needs three main elements; oxygen, light, and PS. Among these elements, PS directly affects the activity of aPDT [20]. To activate the PS at maximum level, it should have the characteristics of high chemical stability, good solubility in water, low dark toxicity, high affinity for microbial cells, preferential accumulation around the pathogenic microorganism, selectively targeting specific cells and high photo-toxicity under light illumination. Porphyrin derivatives, chlorins, phthalocyanine, Rose Bengal, phenothiazines are commonly used as PSs [11]. Mono-LAspartyl-Chlorin e6 (Ce6) is a second-generation PS with chemical purity, low dark toxicity, and easy to synthesize with minimal side effects. It also has the maximum absorption under the red light that is found in the visible region of the electromagnetic spectrum [21]. Since the light absorption capacity of chlorin and its derivatives is at maximum after the irradiation with light in the red portion $(600-700 \mathrm{~nm})$ of the visible spectrum, it has been reported that their activity to produce ROS in the tissue is high in this window after exposure to red light [22]. For these properties to provide the expected effect on living microorganism, the chemical properties of the solvent that is used to dissolve Ce6 play a big role in photoinactivation process. Solvents that increase the capacity to generate more ROS in the environment can be preferred where Ce6 and bacterial cells meet, interact, and then this interaction results in cell death. Less polar solvents such as ethyl alcohol have been reported to increase the antibacterial properties of $\mathrm{Ce} 6$ [23]. It is also known that ethyl alcohol alone causes destruction and death on microorganisms [24]. $\mathrm{EtOH}$ has an increased antimicrobial activity in the presence of water and has two main mechanisms of action that create membrane damage and protein denaturation on the bacterial cell. In membrane damage mechanism, the bacterial membrane integrity is impaired due to the dissolution of membrane lipids in the presence of EtOH. In the protein denaturation mechanism, EtOH causes the proteins in the cell to become dysfunctional. Thus it affects cell metabolism and results in cell lysis at the end [25]. Besides, Pronchnow et al. claimed that the presence of $\mathrm{EtOH}$ reduces the PS aggregation rate compared to water, resulting in high singlet oxygen production, and that the half-life of the produced singlet oxygen in EtOH is 5 times more than the half-life of singlet oxygen produced in the presence of water [26]. Thus, EtOH seems to be a good adjuvant to increase the efficacy of the photoinactivation mechanism because of its antimicrobial properties and being a proper PS solvent for the high quantum yield of singlet oxygen $[25,26]$. 
In this study, it was aimed to analyze the possible effect of $\mathrm{Ce} 6$ as a PS for the photoinactivation of MRSA and the synergistic action of ethanol to improve the mechanism of aPDT with Ce6. Because of the low toxicity, easy synthesis and production, fast and selective accumulation in the target tissue, and high photosensitizing efficacy, it is thought to be effective in obtaining efficient results in aPDT applications on MRSA. To activate Ce6, 655-nm laser light was used as a light source. Then optimum parameters such as energy dose and PS concentration were determined to destroy MRSA efficiently. In the second part of this study, 20\% Ethanol (EtOH) was used as an adjuvant to increase the bactericidal effect of aPDT by lowering the levels of energy dose and $\mathrm{Ce} 6$ concentration.

\section{Material and methods}

\section{Bacterial Strain}

A clinical isolate of MRSA strain was used to analyze the bactericidal effect of aPDT. MRSA from $-80^{\circ} \mathrm{C}$ frozen stock was used in the streaking method to obtain single colonies. Before each experiment, a single colony of MRSA was incubated in tryptic soy broth (TSB) at $37^{\circ} \mathrm{C}$ for $18-24$ hours. And then the suspension was centrifuged and the supernatant was discarded. Centrifuged bacteria were suspended in phosphate-buffered saline (PBS) and made ready for application to be around 108 $\mathrm{CFU} / \mathrm{ml}$.

\section{Photosensitizer and Ethanol}

In this study, the Ce6 agent (Santa Cruz Biotechnology, Dallas, TX, USA), which is in the cationic structure and the chlorin class, was used as PS. Ce6 that has C34H36N4O6 molecular formula and $536.684 \mathrm{~g} /$ mole molecular weight is a second-generation drug that can be used in aPDT applications. Ce6 solutions have been prepared and kept in the dark because of the photobleaching problem of the PS in the light environment. It was dissolved in PBS and applied freshly for each experiment. 1, 2, 5, 10, and $20 \mu \mathrm{M} \mathrm{Ce} 6$ concentrations were used throughout this study.

EtOH was used as an adjuvant to increase the effectiveness of Ce6. The $\mathrm{Ce} 6$ was dissolved in $20 \% \mathrm{EtOH}$ which was obtained by mixing absolute EtOH with distilled water. Ce6 solutions in $20 \% \mathrm{EtOH}$ were prepared at specific concentrations. These solutions were examined at different levels of activity with light applications.

\section{Optical Setup}

A diode-pumped laser device emitting red light at 655 $\mathrm{nm}$ of wavelength was used as a light source (PS4 III.LED, Changchun New Industries Optoelectronics Co. Ltd., Changchun, China). The fiber optic which was used to deliver the light to the cells was placed perpendicularly to the 96-well plate where bacteria were seeded on the optical table. The distance between the optical table and the fiber tip was set to 8.7 $\mathrm{cm}$. The illumination area was $3.14 \mathrm{~cm} 2$ on the optical table. The output power of the light from the optical fiber is 200 milliwatts $(\mathrm{mW})$ and the power density was $63 \mathrm{~mW} / \mathrm{cm} 2$. This diodepumped laser device has a Gaussian beam distribution. To irradiate the cells homogenously with laser light, the core part of the light was used as the illumination area and the energy density of the laser beam was checked by a power meter (Thorlabs, Germany) before each light applications. To obtain the desired antibacterial effect, the optimum laser energy doses were determined by keeping the power density constant and changing the application time. The light intensities applied were 25 and 50 $\mathrm{J} / \mathrm{cm} 2$.

\section{Experimental Procedure}

Six different main groups were formed in the aPDT study using different drug concentrations and different combinations of light energy doses.

1. "Control Group" No light or PS was applied,

2. "Laser Group" Only the laser was applied,

3. "Ce6 Group" Only PS was applied,

4. "EtOH Group" Only 20\% EtOH was applied

5. "aPDT Group" Light and PS were applied together,

6. "aPDT - EtOH Group" Light is applied together with Ce6 dissolved in $20 \% \mathrm{EtOH}$

At the beginning of each experiment, $50 \mu \mathrm{L}$ bacterial solutions were seeded on 96-well plates. All the applications were performed on these plates. After the addition of bacterial solution, the following steps were performed; (1) An equal volume of PBS was mixed with the bacterial solution in Control and Laser groups. (2) An equal volume of Ce6 solution was mixed with the bacterial solution in $\mathrm{Ce} 6$ and aPDT groups. (3) An equal volume of $\mathrm{Ce} 6$ solution in $20 \% \mathrm{EtOH}$ was mixed with the bacterial solution in only EtOH and aPDT-EtOH groups. (4) Then the bacteria were incubated with these solutions for 15 minutes. (5) After incubation, the light was irradiated on bacteria in Laser, aPDT, and aPDT-EtOH groups. (6) When these applications were completed, the serial dilution method was performed to determine the number of live and dead bacterial cells.

\section{Statistical Analysis}

Each experimental group was examined with 3 samples and repeated at least 3 times. All the data obtained from these experimental groups were normalized by the data of the control group. These normalized data were firstly analyzed by one-way ANOVA and then each experimental group was compared with the control group by the Student's t-test. The statistical difference was determined as $\mathrm{p}<0.05$.

\section{Results}

The Effect of Chlorin e6, Light and $20 \%$ EtOH on MRSA

In this study, aPDT with Ce6 was examined on MRSA and then the role of EtOH was analyzed in Ce6-based aPDT applications. First of all, MRSA was incubated with different Ce6 concentrations $(1,2,5,10$, and $20 \mu \mathrm{M})$ to examine whether Ce6 has any dark toxicity on bacteria or not. In these groups where only the PS was applied, similar results were obtained with the control group. Maximum reduction in cell viability was observed with $10 \mu \mathrm{M}$ Ce6 and it was approximately $9 \%$ which cannot be considered as meaningful dark toxicity. Besides, 20 $\mu \mathrm{M}$ Ce6 concentration caused an increase in the bacterial cell population with a rate of $27 \%$. These results showed that only Ce6 application did not have any lethal effects on MRSA bacterial strain (Figure 1). Then the effect of two different energy doses (25 and $50 \mathrm{~J} / \mathrm{cm} 2$ ) was analyzed on MRSA. 25 $\mathrm{J} / \mathrm{cm} 2$ light intensity caused a slight increase in cell number. On the other hand, $50 \mathrm{~J} / \mathrm{cm} 2$ resulted in only a $1 \%$ decrease. Any of them cannot be considered as an effective treatment on bacterial cells. According to these results, it was understood that only laser application with these energy doses had no lethal effect on MRSA, too (Figure 1). Before aPDT applications, the effect of $20 \% \mathrm{EtOH}$ was also examined to understand its antibacterial effect on MRSA. In only $20 \%$ EtOH-treated groups, cell viability decreased by nearly $10 \%$. When it was compared with the control group, it was understood that the effect of $20 \% \mathrm{EtOH}$ did not cause any statistically significant difference in cell viability (Figure 1). 
Figure 1. Bactericidal activity of different light doses, $\mathrm{Ce} 6$ concentrations, and $20 \% \mathrm{EtOH}$ on the viability S. aureus.

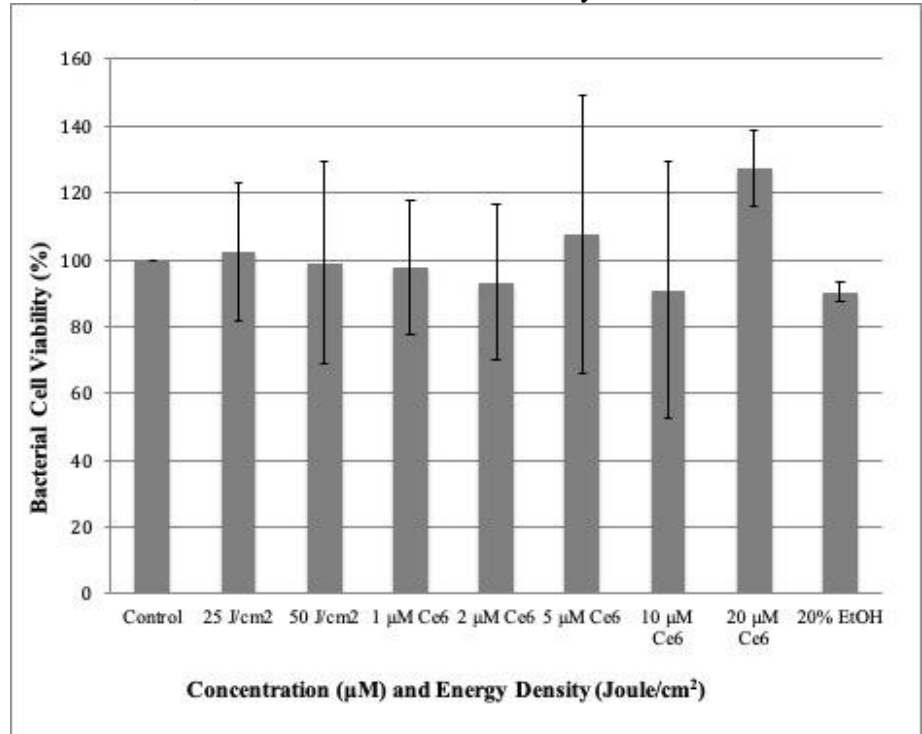

The number of viable cells was counted by colony counting method after laser, Ce6, and $\mathrm{EtOH}$ applications. Data of each experimental group were normalized with the data of the control group (Light dose: 25 and $50 \mathrm{~J} \mathrm{~cm} 2$ and Ce6 concentrations: $1,2,5,10$, and $20 \mu \mathrm{M}$ ).

* shows the statistical significance with respect to the control group and p-value smaller than 0.05 was considered as statistically significant $(\mathrm{n} \geq 8)$.

\section{The Photoinactivation with Ce6 on MRSA}

In aPDT applications, $25 \mathrm{~J} / \mathrm{cm} 2$ light energy was examined together with 4 different Ce6 concentrations $(2,5,10$, $20 \mu \mathrm{M})$. Any of these combinations were successful to eradicate MRSA with more than $99 \%$ mortality rate and they were statistically significant when they were compared with the data of the untreated control group. The most efficient application with a rate of $99.99 \%$ was obtained with $25 \mathrm{~J} / \mathrm{cm} 2$ energy dose and $20 \mu \mathrm{M} \mathrm{Ce} 6$ concentration (Figure 2).

Figure 2. Bactericidal activity of different aPDT doses on the viability of S. aureus.

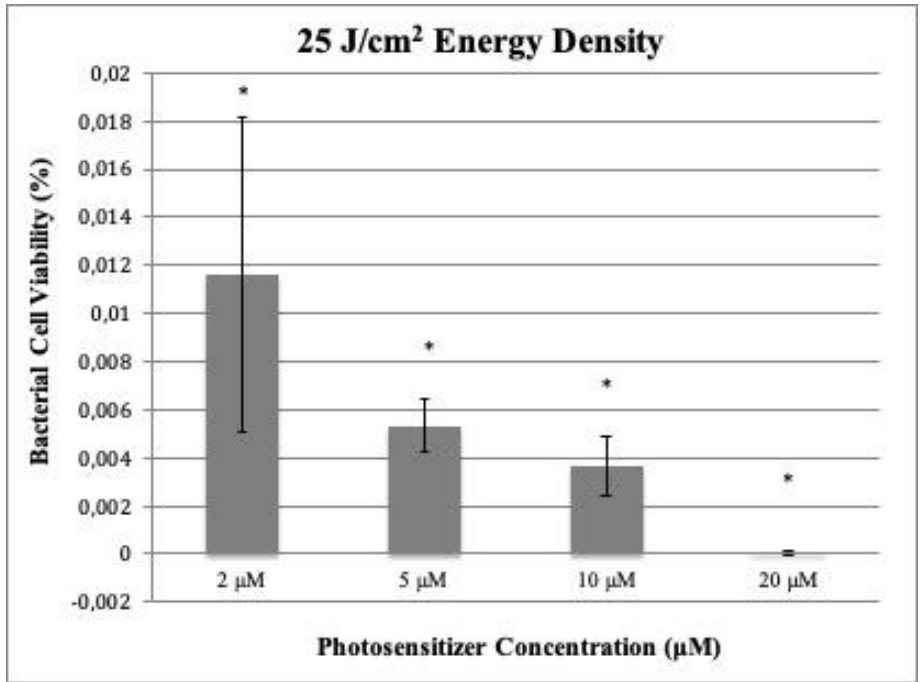

The number of viable cells was counted by colony counting method after aPDT applications Data of each experimental group were normalized with the data of the control group (Light dose: $25 \mathrm{~J} \mathrm{~cm} 2$ and Ce6 concentrations: 2, 5, 10, and $20 \mu \mathrm{M}$ ).

$*$ shows the statistical significance with respect to the control group and $\mathrm{p}$-value smaller than 0.05 was considered as statistically significant $(\mathrm{n} \geq 8)$.

Then $50 \mathrm{~J} / \mathrm{cm} 2$ energy dose was applied with 4 different Ce6 concentrations $(1,2,5,10 \mu \mathrm{M})$ on MRSA. By using more intense light, $\mathrm{Ce} 6$ concentration was reduced to its half which was $10 \mu \mathrm{M}$ to obtain the same bactericidal effect with a rate of 99.99\% (Figure 3).
Figure 3. Bactericidal activity of different aPDT doses on the viability of S. aureus.

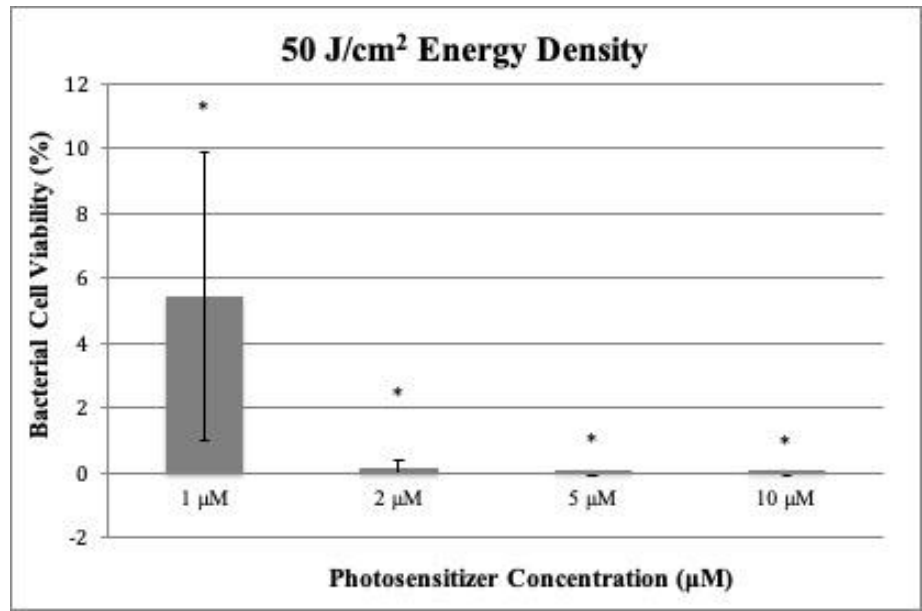

The number of viable cells was counted by colony counting method after aPDT applications. Data of each experimental group were normalized with the data of the control group (Light dose: $50 \mathrm{~J} \mathrm{~cm} 2$ and Ce6 concentrations: 1, 2, 5, and $10 \mu \mathrm{M})$. Each column indicates normalized data \pm standard deviation $(\mathrm{n}>8)$.

* shows the statistical significance with respect to the control group and $\mathrm{p}$-value smaller than 0.05 was considered as statistically significant $(n \geq 8)$.

\section{Photoinactivation}

The Effect of $20 \%$ EtOH in Ce6-based

To examine the effect of EtOH in the photoinactivation process, Ce6 solutions were prepared in $20 \%$ EtOH. 3 different Ce6 concentrations $(1,2,5 \mu \mathrm{M})$ were examined with $25 \mathrm{~J} / \mathrm{cm} 2$ energy dose. As shown in Table 1, These Ce6 concentrations were capable to create more than $99 \%$ antibacterial activity when they were in $20 \%$ EtOH solution after the irradiation by $25 \mathrm{~J} / \mathrm{cm} 2$ laser light. The most effective application was performed with 2 $\mu \mathrm{M} \mathrm{Ce} 6$ in $20 \%$ EtOH. Thus, the adjuvant effect of EtOH on MRSA has shown a significant lethal effect with less amount of Ce6 under light illumination (Table 1).

Table 1. Percentage decrease in the viability of S. aureus after Ce6mediated photoinactivation process with/without EtOH.

\begin{tabular}{|c|c|c|c|}
\hline \multirow[b]{2}{*}{$\begin{array}{l}\text { Ce6 } \\
\text { Concentration } \\
(\mu \mathrm{M})\end{array}$} & \multicolumn{3}{|c|}{ \% Decrease in Cell Viability } \\
\hline & $\begin{array}{l}\text { aPDT with } 25 \\
\mathrm{~J} / \mathrm{cm}^{2}\end{array}$ & $\begin{array}{l}\text { aPDT with } 50 \\
\mathrm{~J} / \mathrm{cm}^{2}\end{array}$ & $\begin{array}{l}\text { aPDT with } 25 \\
\mathrm{~J} / \mathrm{cm}^{2}+20 \% \\
\text { EtOH }\end{array}$ \\
\hline $1 \mu \mathrm{M} \mathrm{Ce} 6$ & - & 94.5381 & 99.9962 \\
\hline $2 \mu \mathrm{M} \mathrm{Ce} 6$ & 99.9884 & 99.8318 & 99.9999 \\
\hline $5 \mu \mathrm{M} \mathrm{Ce} 6$ & 99.9947 & 99.9904 & 99.9988 \\
\hline $10 \mu \mathrm{M} \mathrm{Ce} 6$ & 99.9963 & 99.9990 & - \\
\hline $20 \mu \mathrm{M} \mathrm{Ce} 6$ & 99.9999 & - & - \\
\hline
\end{tabular}

\section{Discussion}

In this study, the photoinactivation capability of $\mathrm{Ce} 6$ was examined with a $655 \mathrm{~nm}$ laser light on MRSA. Then EtOH was used to increase the bactericidal effect of this mechanism by lowering the Ce6 concentration. When any of these parameters which are PS, light, or EtOH was used alone, it desired not to cause any bactericidal activity to limit the side effects of this mechanism. aPDT can be considered as successful when it is applied to the infected area of the biological tissue without giving any harm to the neighboring tissue. Different Ce6 concentrations $(1,2,5,10$, and $20 \mu \mathrm{M})$ did not cause any dark toxicity on MRSA when applied alone. The maximum reduction in cell viability was obtained with $10 \mu \mathrm{M} \mathrm{Ce} 6$ and it was around $9 \%$. When their impacts were analyzed statistically, none of them showed any difference from the untreated control group. Similar results were obtained with the application of only light (25 and $50 \mathrm{~J} / \mathrm{cm} 2$ ) and only $20 \%$ EtOH treatments. Light treatments resulted in a slight change in bacterial cell viability. $20 \% \mathrm{EtOH}$ application decreased the cell viability with a rate of 
nearly $10 \%$. None of them were statistically different from the control groups. It can be concluded that these parameters cannot cause any significant cell death when they were applied alone.

When the aPDT groups that were received $25 \mathrm{~J} / \mathrm{cm} 2$ laser irradiation were examined, more than $99 \%$ cell death was achieved with any of the Ce6 concentrations. The most successful one was the treatment with $20 \mu \mathrm{M}$ Ce 6 irradiated by $25 \mathrm{~J} / \mathrm{cm} 2$. This treatment resulted in more than $99.99 \%$ cell death. The general purpose of aPDT is to obtain the maximum cell death with minimum light energy dose and $\mathrm{Ce} 6$ concentration. Among these parameters, the PS is the most possible toxic element of these applications. So it is always desired to minimize the concentration level of PSs. To increase the bactericidal capacity of PS in aPDT with lower concentrations, light energy dose must be increased [27]. Therefore, light energy was increased to $50 \mathrm{~J} / \mathrm{cm} 2$ and its effect was examined with 4 different $\mathrm{Ce} 6$ concentrations $(1,2,5$, and $10 \mu \mathrm{M}) .1 \mu \mathrm{M} \mathrm{Ce} 6$ concentration caused a cell death with a rate of $94 \%$ which was quite high but not efficient to eradicate bacterial population with an acceptable range. When the concentration of $\mathrm{Ce} 6$ was increased slightly, aPDT applications resulted in more than $99 \%$ cell death. Among the Ce6 concentrations used with $50 \mathrm{~J} / \mathrm{cm} 2$, the best result was obtained with $10 \mu \mathrm{M}$ Ce6 concentration.

In aPDT groups using 25 and $50 \mathrm{~J} / \mathrm{cm} 2$ laser energy doses, the desired more than $99.99 \%$ bacterial viability reduction was seen in experimental groups containing $20 \mu \mathrm{M}$ and $10 \mu \mathrm{M}$ Ce6 concentrations, respectively. Although $50 \mathrm{~J} / \mathrm{cm} 2$ is higher energy level when compared to $25 \mathrm{~J} / \mathrm{cm} 2$, it showed less bactericidal activity when its effect was compared with the effect of PS alone, which means that these energy doses of red light were not as harmful as PS itself. The aim of the work is to achieve maximum bacterial cell death at the minimum laser energy dose and PS concentration and also to avoid the lethal effect of the PS or laser alone. Therefore, the aPDT group containing $50 \mathrm{~J} / \mathrm{cm} 2$ and $10 \mu \mathrm{M}$ Ce 6 concentration was accepted as the desired doses for the photoinactivation process.

In the second part of this study, EtOH was used as an adjuvant to increase the effect of aPDT with a lesser amount of light dose and PS concentration. In this part, $25 \mathrm{~J} / \mathrm{cm} 2$ energy dose was examined with 1,2 , and $5 \mu \mathrm{M}$ Ce6 concentrations. With the addition of $20 \%$ EtOH to the mechanism, more than $99.99 \%$ cell death was achieved with any of these Ce6 concentrations. The most efficient antibacterial activity was obtained with $2 \mu \mathrm{M}$ Ce6. The use of $20 \%$ EtOH provides the opportunity to decrease PS concentration level in a significant amount (10X reduction according to the application with 25 $\mathrm{J} / \mathrm{cm} 2,5 \mathrm{X}$ reduction according to the application with $25 \mathrm{~J} / \mathrm{cm} 2$ ). So it will be a promising strategy in aPDT applications to avoid the lethal effect of the drug alone. It is thought that EtOH increases bacterial wall permeability and penetration capability of Ce6 into the cells [26].

In conclusion, the aim of this study was to develop an alternative antibacterial mechanism that can completely destroy MRSA strains. The desired effects were achieved in both EtOHfree and $\mathrm{EtOH}-$ containing applications with $\mathrm{Ce} 6$ and 655-nm laser light. Significantly high bactericidal effects were obtained at a lower level of red light and $\mathrm{Ce} 6$ concentration in this study. Achieving the maximum levels of cell death with such low quantities of Ce6 levels reflects the success of the Ce6-based aPDT with and without EtOH. Thus, using $\mathrm{Ce} 6$ as a PS in the presence of $655-\mathrm{nm}$ laser light can be a good candidate for the elimination of local infections caused by MRSA clinically.

\section{Acknowledgments}

This study was supported by the İzmir Katip Çelebi
University Scientific Research Projects (2015-ÖNP-MÜMF0017 to N.T.). The authors thank Nesrin Horzum Polat, Melike Çağan, Fatma İbiş, and Nur Çobanoğlu for their help and valuable opinions.

\section{References}

1. Saïd-Salim B, Mathema B, Kreiswirth BN. Communityacquired methicillin-resistant Staphylococcus aureus: an emerging pathogen. Infect Control Hosp Epidemiol. 2003; 24: 451-455.

2. Dulon M, Haamann F, Peters C, Schablon A, Nienhaus A. MRSA prevalence in European healthcare settings: a review. BMC Infect Dis. 2011; 11: 138.

3. Miller LG, Diep BA. Colonization, fomites, and virulence: rethinking the pathogenesis of community-associated methicillinresistant Staphylococcus aureus infection. Clin Infect Dis. 2008; 46: 752-760.

4. Wenzel RP, Perl TM. The significance of nasal carriage of Staphylococcus aureus and the incidence of postoperative wound infection. J Hosp Infect. 1995; 31: 13-24.

5. Kucera J, Sojka M, Pavlik V, Szuszkiewicz K, Velebny V, Klein P. Multispecies biofilm in an artificial wound bed-A novel model for in vitro assessment of solid antimicrobial dressings. J Microbiol Methods. 2014; 103: 18-24.

6. Pardoll DM. The blockade of immune checkpoints in cancer immunotherapy. Nat Rev Cancer. 2012; 12: 252-264.

7. Khan AA, Morrison A, Hanley DA, Felsenberg D, McCauley LK, O'Ryan F, et al. Diagnosis and management of osteonecrosis of the jaw: a systematic review and international consensus. J Bone Miner Res. 2015; 30: 3-23.

8. Tverdek FP, Crank CW, Segreti J. Antibiotic therapy of methicillin-resistant Staphylococcus aureus in critical care. Crit Care Clin. 2008; 24: 249-260.

9. Nau R, Eiffert H. Modulation of release of proinflammatory bacterial compounds by antibacterials: potential impact on course of inflammation and outcome in sepsis and meningitis. Clin Microbiol Rev. 2002; 15: 95-110.

10. Mai B, Wang X, Liu Q, Leung AW, Wang X, Xu C, et al. The antibacterial effect of sinoporphyrin sodium photodynamic therapy on Staphylococcus aureus planktonic and biofilm cultures. Lasers Surg Med. 2016; 48: 400-408.

11. Fu XJ, Fang Y, Yao M. Antimicrobial photodynamic therapy for methicillin-resistant Staphylococcus aureus infection. Biomed Res Int. 2013; 2013.

12. Benveniste RAOUL, Davies J. Mechanisms of antibiotic resistance in bacteria. Annu Rev Biochem. 1973; 42: 471-506.

13. Klein E, Smith DL, Laxminarayan R. Hospitalizations and deaths caused by methicillin-resistant Staphylococcus aureus, United States, 1999-2005. Emerg Infect Dis. 2007; 13: 1840.

14. Lowy, FD. Antimicrobial resistance: the example of Staphylococcus aureus. J Clin Invest. 2003; 111: 1265-1273.

15. Lowy FD. Staphylococcus aureus infections. N Engl J Med. 1998; 339: 520-532.

16. Peacock Jr JE, Moorman DR, Wenzel RP, Mandell GL. Methicillin-resistant Staphylococcus aureus: microbiologic characteristics, antimicrobial susceptibilities, and assessment of virulence of an epidemic strain. J Infect Dis. 1981; 144: 575-582.

17. Yılmaz EŞ, Aslantaş Ö. Antimicrobial resistance and underlying mechanisms in Staphylococcus aureus isolates. Asian Pac J Trop Biomed. 2017; 10: 1059-1064.

18. Capparelli R, Parlato M, Borriello G, Salvatore P, Iannelli D. Experimental phage therapy against Staphylococcus aureus in mice. Antimicrob Agents Chemother. 2007; 51: 2765-2773.

19. Liu Y, Qin R, Zaat SA, Breukink E, Heger M. Antibacterial photodynamic therapy: overview of a promising approach to fight antibiotic-resistant bacterial infections. J Clin Transl Res. 2015; 1: 140.

20. Mai B, Gao Y, Li M, Wang X, Zhang K, Liu Q, et al. Photodynamic antimicrobial chemotherapy for Staphylococcus aureus and multidrug-resistant bacterial burn infection in vitro and in vivo. Int J Nanomedicine. 2017; 12: 5915. 
21. Čunderlíková B, Gangeskar L, Moan J. Acid-base properties of chlorin e6: relation to cellular uptake. J Photochem and Photobiol B. 1999; 53: 81-90.

22. Sheyhedin I, Okunaka T, Kato H, Yamamoto Y, Sakaniwa N, Konaka C, Aizawa K. Localization of experimental submucosal esophageal tumor in rabbits by using mono-L-aspartyl chlorin e6 and long-wavelength photodynamic excitation. Lasers in Surgery and Medicine. 2000; 26(1): 83-89.

23. George S, Kishen A. Photophysical, photochemical, and photobiological characterization of methylene blue formulations for light-activated root canal disinfection. J Biomed Opt. 2007; 12: 034029.

24. Price PB. Reevaluation of ethyl alcohol as a germicide. Arch Surg. 1950; 60: 492-502.

25. McDonnell G., Russell AD. Antiseptics and disinfectants: activity, action, and resistance. Clin Microbiol Rev. 1999; 12: 147-179.

26. Prochnow EP, Martins MR, Campagnolo CB, Santos RC, Villetti MA, Kantorski KZ. Antimicrobial photodynamic effect of phenothiazinic photosensitizers in formulations with ethanol on Pseudomonas aeruginosa biofilms. Photodiagnosis Photodyn Ther. 2016; 13: 291-296.

27. Topaloglu N, Gulsoy M, Yuksel S. Antimicrobial photodynamic therapy of resistant bacterial strains by indocyanine green and 809-nm diode laser. Photomed Laser Surg. 2013;31:155-62. 